Working

Paper

Department

of Economics

$\mathrm{Ca}^{\prime}$ Foscari University of

Venice

Luciano Pezzolo

Giuseppe Tattara

Una fiera senza luogo.

Was Bisenzone an

offshore capital market in

sixteenth-century Italy? 


\title{
Una fiera senza luogo. Was Bisenzone an offshore capital market in sixteenth-century Italy?
}

\author{
Luciano Pezzolo \\ University of Venice \\ Giuseppe Tattara \\ University of Venice
}

\begin{abstract}
This paper discusses how Genoese bankers collected money at exchange fairs. This money was then lent to the King of Spain - through the asientos - from the mid-sixteenth to the early seventeenth centuries. Genoese bankers raised capital at the exchange fairs , which were typical short-term credit mechanism, where foreign bills of exchange were discounted over a three-month period. The Genoese funded long-term obligations by means of short term loans which meant they were able to enforce payment to the King and at the same time successfully manage the supply of finance from a large number of easily substitutable markets, located in different states. The Bisenzone fair of exchange was the forerunner to an efficient, widely integrated international capital market where Genoese preeminence was firmly established and which the Genoese kept firmly under their control. The success of the Bisenzone fairs of exchange directly challenges the theory which suggests that the laws against usury restrained the development of capital markets in early modern Italy.
\end{abstract}

\section{Keywords}

Financial markets, market integration, financial institutions

\section{JEL Codes}

N20, N23, N43

\author{
Address for correspondence: \\ Luciano Pezzolo \\ Department of Economics \\ Ca' Foscari University of Venice \\ Cannaregio 873, Fondamenta S.Giobbe \\ 30121 Venezia - Italy \\ Phone: (++39) 0412349150 \\ Fax: (++39) 0412349176 \\ e-mail: pezzolo@unive.it
}

This Working Paper is published under the auspices of the Department of Economics of the Ca' Foscari University of Venice. Opinions expressed herein are those of the authors and not those of the Department. The Working Paper series is designed to divulge preliminary or incomplete work, circulated to favour discussion and comments. Citation of this paper should consider its provisional character.

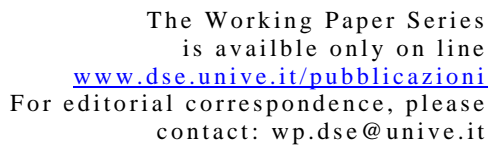

The Working Paper Series

is availble only on line www.dse.unive.it/pubblicazion

For editorial correspondence, please

contact:wp.dse@unive.it

Department of Economics

Ca' Foscari University of Venice

Cannaregio 873, Fondamenta San Giobbe

30121 Venice Italy

Fax: ++390412349210 


\section{Introduction}

Over the sixteenth and seventeenth centuries the kings of Spain fought long and costly wars and borrowed extensively to finance fluctuations in military expenditure. The Crown was financed domestically by means of perpetual 5percent bonds - juros - and contracted international credit through the asiento, a short-term high interest loan frequently underwritten by foreign merchant bankers. Asientos were short term only in principle, and many asientos were issued to roll over other asientos that the Crown could not fully pay.

The King's main foreign lenders were Genoese bankers, who raised money mainly on the fairs of exchange, a short-term international capital market where bills of exchange were discounted for three-month periods and frequently renewed. The position of the Genoese bankers reminds us of modern-day banks, who loan to less developed countries and link the repayment of long-term loans to the provision of short-term credit.

In light of the large sums owed to them by a Crown that underwent several "bankruptcies" (in 1557, 1560, 1575, 1596 and 1607), Genoese bankers might have been unable to clear the letters of exchange issued on European fairs. The chain of trust which linked the Spanish King to the small investor - in the opinion of some observers - looked very weak ${ }^{1}$.

This was not the case, however. The main question is how the Genoese were able to survive the suspension or rescheduling of payments by their debtors, if their creditors proved to be very short-term creditors. The answer is twofold. First, the Genoese had the upper hand on their debtor. They were able to enforce their payments to the King of Spain whose subsequent bankruptcies eventually ended in debt rescheduling, i.e. swapping long term domestic debt for short term international debt ${ }^{2}$, so the bankruptcies essentially posed a problem of liquidity ${ }^{3}$. Second, Genoese bankers were the main actors in the international capital market, represented by the fair of Bisenzone, where local crises could be absorbed by other financial centers and bills of exchange continued to be cleared.

The financing operations conducted through the Bisenzone fair can be interpreted as loan contracts that offered the borrower fixed rate interest which was unaffected by exchange fluctuations. The Bisenzone fair was a Genoese institution which operated under Genoese law. Creditors from other cities were drawn to it because the interest rates were generally higher than other alternatives on offer, risk could be spread among various investors, and the short-term credit instruments [described in detail below] were easily rolled over and extended. But this was a market ultimately controlled by the Genoese authorities, who could declare moratorium on debt contracts and enforce renegotiation upon creditors.

The paper is organized as follows. Section two describes the strategic factors that led to the development of the Bisenzone fair of exchange, the Genoese fair, and to Genoese enrichment. Section three analyses the fair of Bisenzone in the context of the international capital market and discusses the integration of the Genoese market with the credit markets in Milan, Florence and Venice, observing the parallel move in interest rates expressed in different currencies and their rapid adjustments. The financing of foreign bills of exchange took place through the pactum de ricorsa, which was a significant innovation that contrasted the 'dry exchange' process classically described by De Rover. The laws against loans at interest seem not to

\footnotetext{
${ }^{1}$ Contarini, Istorie, cc. $175 \mathrm{r}-78 \mathrm{r}$.

${ }^{2}$ The royal "bankruptcy" was in fact a new deal between the king and his creditors. See Thompson, "Castile". On some occasions payments were made in very depreciated juros, according to Peri, Negotiante, pt. 1, p. 48.

${ }^{3}$ Braudel, Civiltà, pp. 541-43; Conklin, “Theory”.
} 
have restrained the development of capital markets in early modern Italy, despite its traditional historiography ${ }^{4}$. Conclusions follow.

\section{The fairs of exchange: Bisenzone}

Between the late sixteenth and early seventeenth centuries, exchange fairs succeeded in raising large sums of money in the form of medium and short term loans and occupied the center stage of the European financial market. The organization of fairs has to be set within the broader context of financial markets in Europe at that time. In Italy, several public institutions dealt with credit (the Banco di San Giorgio in Genoa, the Banco della Piazza di Rialto and the Banco Giro in Venice, the Banco di Sant' Ambrogio in Milan), but their activities were limited mostly to deposits and transfers, together with operations concerning state finance. Besides these public institutions, private firms also acted as banks; their reliability, though, often left much to be desired and their role within the whole financial market was rather limited. Moreover, the development of such institutions, both public and private, was strongly influenced by norms against usury. The so-called Genoese fairs, founded in Besançon in 1535 (hence the name, "Bisenzone" which was retained even when the fair moved) and transferred to Piacenza in 1579 and later to Novi Ligure, provided a device, which among other things, served both to avoid ecclesiastic censure and to raise loans in a period of great tension.

Moving the fairs from Lyon to Piacenza brought about a twofold change that occurred in the European capital market between the late sixteenth and the early seventeenth centuries. Firstly, unlike the typical late-medieval fairs, the fair of Bisenzone set up a financial market which was completely unbound by commercial activities. Secondly, a relatively restricted group of Genoese bankers succeeded in exercising control over major financial mechanisms.

The difficulties of the Lyon market weakened the role played by Tuscan financiers, who were traditionally tied to the French Crown: this context led to the emergence of Genoese bankers, who were consolidating their relations with Castile and establishing themselves as the main interlocutors of the Habsburg treasury, at least up until the $1630 \mathrm{~s}^{5}$. Despite the exploitation of the imported commodities from America, Castile had to cope with a serious gap between its own financial means and the enormous need to finance its grandiose imperial policy. The desperate need for money was one of the common features that characterized the policy of Charles $\mathrm{V}$ and his successors until the end of the seventeenth century. In the early 1570s, for example, the cost of the Spanish army which was engaged in the war in Flanders, was estimated to be 1.2 million florins a month, while only half this amount was actually available ${ }^{6}$. The most important task of the Spanish Crown was to ensure a regular flow of payments to the troops engaged at the various fronts. Since the much needed funds were not received on a regular basis, and the royal administrators could not transfer the money required, it was necessary to rely on money advanced by financiers. The latter were responsible for making payments at due dates, on agreed locations, and in accepted local coinage; the King, on the other hand, was committed to paying back the amount in accepted coinage or in precious metal by an agreed date.

Repayments were made in Spain or, after 1580, either in Italian or Antwerp in accordance with a pre-established exchange agreement. Lenders, moreover, enjoyed the privilege of carrying out of Spain an amount of silver as collateral

\footnotetext{
${ }^{4}$ Neal, "How it all began".

${ }^{5}$ Da Silva, Banque, p. 196; Boyer-Xambeau, Deleplace, Gillard, Banchieri, pp. 303 ff.

${ }^{6}$ Parker, Army, p. 136.
} 
which was equal to the sum granted as a loan (licencias de saca) ${ }^{7}$. This deal, known as asiento, implied a short term loan by the financiers to the King. Furthermore, there was another kind of asiento, usually signed by the Spanish governor in Flanders: the governor, in urgent need for money, underwrote a loan to be paid back at a later date by the Treasury in Spain. The borrowing capacity of the Spanish Crown was strengthened both by the influx of American silver from the mid-sixteenth century onwards and the assignment of tax collection to the bankers. Continuous delays with payments and the mounting up of arrears provoked a series of mutinies that endangered the outcome of the war against the United Provinces. It was necessary, therefore, to ensure a constant flow of cash to the troops, who insisted that their wages be paid in silver and gold coins, to protect them from the constant debasement of the petty currency ${ }^{8}$. Between 1520-32 and 1552-56 the amount of debt through asientos increased from 5.4 to 9.6 millions ducats and before 1608 - the first year of truce with the United Provinces - about $68 \%$ of the money raised through asientos was directed to the Flanders. Resort to asientos was onerous because of the difficulty of the Crown to reimburse lenders in due time ${ }^{9}$

A great deal of these flows was under Genoese control. It has been argued that in the years 1598-1609 the bankers of the Ligurian republic lent straight to the Spanish Crown about 33 million ducats, namely $88 \%$ of the whole amount of loans signed by the King. Likewise, in the years 1623-26 the Genoese provided $13,664,000$ ducats $^{10}$. It is just from 1579 that "Bisenzone" began to play a crucial role for the international payment system. At Bisenzone, in fact, Genoese bankers succeeded in changing their credits in Spanish silver into foreign bills of exchange in gold provided by Tuscan, Lombard, and above all Venetian merchants. The high Venetian demand for silver was due to the fact that Rialto at that time was one of the most important centers for the redistribution of silver to the Levant, where silver could be exchanged with gold at a very favorable rate. ${ }^{11}$

The success of the Genoese fairs is proved by the volume of business. It has been argued that between the sixteenth and the seventeenth centuries the total value of transactions in one year could be as high as forty million gold scudi ${ }^{12}$. But, besides their unquestionable aptitude in raising money from various markets, Genoese hegemony was sustained by the favorable balance of trade enjoyed by Italy compared with that of Spain, Southern Flanders and Germany ${ }^{13}$.

There was no need to transfer gold: gold piled up in Antwerp because of the healthy turnover of trade in Flanders. Flanders had a surplus balance with Northern Europe (Germany, England) and accumulated gold and silver. ${ }^{14}$

The Genoese could get their hands on silver through their commitment to pay gold to the Spanish troops in Flanders. As long as the Spanish were prepared to continue their 80 years war with Flanders, Genoa and most of the towns along the Bisenzone

\footnotetext{
${ }^{7}$ Secondly, the license to export gold or silver was very attractive because of the fees which could later be charged to merchants needing to remit in either gold or silver to other trade centers. Profits to the bankers therefore came from the commission, the exchange and the license to export precious metals. Major lenders received political benefits as well: appointments as royal officers, grants of fiefs and various privileges.

${ }^{8}$ Vàzquez de Prada , “Uomini”, p. 255; Braudel Civiltà, pp. 539-40; but also Quatrefages, Tercios, pp.184-85.

${ }^{9}$ Gelabert, Castile, pp. 207-216.

${ }^{10}$ Doria, “Conoscenza”, pp. 69-70. In 1607 royal income in Castile was 12,5 million ducats; and in the years 162140 it averaged about 17 millions. Thompson, "Castile”, p. 157.

${ }^{11}$ This was another reason why Venetian merchants opposed an attempt by the Senate to prohibit exchanges with the Genoese in 1639. See Mandich, Pacte, p. 33 n.15.On gold/silver ratio in Europe and Asia, Kindleberger, Spenders, pp. 74-75; Pezzolo, Economia, p. 95. Trade with the Levant was paid either through barter or by sending silver. Foreign bills of exchange were not an accepted means of payment.

${ }^{12}$ Felloni, “Asientos”, p. 534.

${ }^{13}$ Braudel, Civiltà, p. 534 ; Brulez, “Exportation”; Goris, Etudes, p. 319 ; and Lettres, p. 66.

${ }^{14}$ On this point Chaudhuri, “Economic Problems”, pp. 339-344 and Brulez, “Handelsbalans”, pp. 304-309.
} 
transfer route, could sell gold at very favorable prices in exchange for silver and this was one of the contributing factors to their increased wealth. ${ }^{15}$

The role of the Genoa transfer route progressively declined after the 1607 suspension: the Genoese were no longer able to face the growing needs of the King who quickly turned to the Portuguese ${ }^{16}$. Portuguese bankers were willing to provide the money needed to meet the increasing demands of the monarchy and so replaced the Genoese - although not completely - from $1626^{17}$. The Portuguese phase lasted up to 1650, when the Dutch seized their profits from the Far East and Brazil. The emergence of Portuguese financial aid, however, marked the replacement of the Mediterranean financial circuits with a broader system which centred on the Atlantic and Asian trade.

\section{Collecting money at the fair.}

The Genoese fairs of exchange were places where bankers met in order to either pay off former deals or make new ones ${ }^{18}$. These fairs can be regarded as forerunners of the modern clearing houses, for operators could offset their credits and debits and regulate the balance either by issuing foreign bills of exchange on their creditors or by buying a particular currency of account which was the Scudo di Marco.

However, the function of the Genoese fairs was not limited to clearing accounts or even to currency exchange. Bisenzone performed a financing operation as well; silver was received from time to time, while gold for the army was to be paid regularly, to avoid military revolts ${ }^{19}$. This was accomplished through the typical instrument of the fairs - the "rechange" (pactum de ricorsa).

An exchange transaction consisted of supplying local currency against the delivery of foreign currency abroad at maturity. Exchange took place through the issue of a commercial bill. Foreign bills of exchange were the most widely used means of payment at the time: payment in gold, silver (coined or bullion) was much more expensive and unsafe and the use of metal was limited to trade with more distant countries $^{20}$.

The financial bill or "rechange" transaction involved repeating the exchange transaction in reverse. The payee of the original bill was now the remitter and the original payer became the drawer. At the end of a "rechange" operation, the original drawer had his loan repaid, gross of interest and in the same currency in

\footnotetext{
${ }^{15}$ See footnote 5 and Braudel, Civiltà, p.539.

${ }^{16}$ Girard, “Etrangers”; Castillo Pintado,”Monarchie espagnole”; Boyajian, Portuguese; Broens, Monarquia.

${ }^{17}$ Bitossi, Governo.

${ }^{18}$ Bisenzone was the only fair where credit and debits could balance internationally, from Florence to Kracov. Other Italian fairs, such as Verona or other minor fairs, were never able to attract foreign bankers, who did not have their correspondents in Verona, or in other small towns, and so were not able to pay their bills and cash their credits there. See Mandich, Pacte, p.111, n.79.

Fairs are seen as the precursors to the clearing houses, since bankers could clear their credits and debits and pay the balance through the issue of foreign bills of exchange addressed to their creditors or through the purchase of a conventional currency which was the Scudo di Marco.

For a description of the working of the fairs and the role of Venice in the early $16^{\text {th }}$ century, see Contarini, Historie, c. $175 \mathrm{r}$

${ }^{19}$ Boyer-Xambeau, Deleplace, Gillard, “Crise”, p.154.

${ }^{20}$ Spain had a passive balance with other European countries because of its imperial policy and the war in the United Provinces which was balanced by exporting silver from America. One important transfer route of silver was through Genoa and Northern Italian towns. Venice played an important role in this. Venice was in debt because of her silver imports. It had a passive trade balance with the Levant, which was paid in silver, and an active trade balance with Northen Europe. Part of the Venetian surplus to certain North European countries, such as Germany and France, served to repay the imported silver, through the transfer of gold payments to the King of Spain in Antwerp. The transfer payment was through the issue of foreign bills of exchange requesting the North European debtors at the Antwerp fair, to pay gold on behalf of the Venetians, to the soldiers fighting for the King of Spain. There was no need to transfer gold: gold piled up in Antwerp because of the positive Flemish balance of trade. Flanders had a surplus balance with Northern Europe (Germany, England) and cumulated gold and silver.
} 
which it had originally been conceded. When the obligation matured, it was selfliquidating. But the parties to the "loan-via-rechange" could agree to renew it for one or more returns. In such a way the "exchange-rechange" lost any connection to trade and appeared as a pure financing transaction ${ }^{21}$.

The pactum de ricorsa, which formalized the financing transaction in Genoese law, was an agreement by which a bill drawn on a fair was automatically redrawn at rates established by fair officials. In Bisenzone the rate of redraft - and thus the rate of interest - was fixed at the time the loan contract was drawn up. Through the device of exchange and "rechange" a wide area of savers was involved in the system of international finance. ${ }^{22}$ Although some "rechange" contracts date back to from the thirteenth century ${ }^{23}$, they experienced their major diffusion in the Genoese fairs between the sixteenth and the seventeenth centuries, with the increasing demand for money from the Spanish Crown.

In its simplest form exchange/"rechange" financing in Bisenzone can be illustrated by reworking the following example from a contemporary merchant, Giandomenico Peri ${ }^{24}$.

The King of Spain was in need of a large amount of money in Antwerp (500,000 ducats), which he did not have, and there were no merchants in Madrid able to credit such a huge amount of money in Antwerp on the King's account. The King sold (passa) an asiento to a Genoese negotiante in Madrid, as the grounds for lending him money for the stated amount, to be paid in Antwerp at the expiry date, il servitio. The negotiante ordered his correspondent in Genoa to transfer 500,000 ducats to Antwerp. The correspondent in Genoa issued a bill of exchange to raise the sum at the fair from merchant bankers in Genoa, Milan and Florence. Let us consider Milan only. The Milanese had the bill immediately accepted by a Milanese banker (rechanger) by promising him immediate "rechange", so as to delay payment until the next fair. "Rechange" meant that the correspondent, with the proceeds of the bill drawn on the rechanger, was able to purchase a bill drawn on Genoa which would not mature until the next fair.

At the fair, the drawee, who was faced with the need to raise fresh cash to deal with the rather infrequent repayments made by the King of Spain, sent the bill of exchange and used "rechange" as a form of financing. The second part of this operation, the "rechange", ended a cycle that in principle lasted a trimester, but that could be extended to several years.

The stage, where the protagonists are the imperial government in Madrid, the soldiers of the tercios in Flanders, the Flemish and Italian merchants, the Genoese financiers and a great deal of investors all had the exchange fairs of "Bisenzone" as a common backdrop.

\section{The mechanism of the Bisenzone fair .}

Fairs were held four times a year: the fair of the Presentation at the temple on February $1^{\text {st }}$; the Easter fair on May $2^{\text {nd }}$; the third fair on August $1^{\text {st }}$, and lastly the fair of All Saints on November $2^{\text {nd }}$. Each fair lasted eight days and followed specific procedures. On the first day every banker or cambista - people dealing with exchanges - established his net balance towards the others. The rate of exchange was fixed according to reciprocal credits and debits and, the third day, a bilateral offset of credits and debits took place. All this was immediately sorted out because operations were based on a common currency which was the Scudo di

\footnotetext{
${ }^{21}$ Mandich, Pacte, p. 57; Boyer-Xambeau, Deleplace, Gillard, “Crise”.

${ }^{22}$ Mandich, Pacte, pp. $83 \mathrm{ff}$.

${ }^{23}$ Mueller, Venetian money, pp. 288-94.

${ }^{24}$ Peri, Negotiante, pt. 2, p. 82
} 
Marco. At the close of the fair a general settlement was carried out. Since bankers at the fair represented the major markets, the credits and debits usually balanced out or were made to balance ${ }^{25}$.

Exchange and "rechange" at the fairs were the result of an agreement: nations participating in the fair elected a panel of bankers who, along with the Magistrate, fixed the rate of exchange to be used during the fair: this procedure was called 'to put account' or 'exchange or price of account ${ }^{\text {,2 }}$. Exchange and "rechange" were set in units of money against an ideal unit, the Scudo di Marco. The Scudo di Marco was convertible into gold at a fixed rate, 100 Scudo di Marco against 101 gold Scudo delle cinque stampe (namely the Scudo of Venice, Milan, Genoa, Naples, and Castile) ${ }^{27}$; but it is worth pointing out that convertibility was more an exception rather than the rule, for it was seldom requested or at least only for small amounts, when there was a situation of imbalance ${ }^{28}$.

The exchange rate negotiated at the fair was not an obligatory market price (manual exchange). It was agreed by the bankers' committee and was written on the bill of exchange. It was referred to as cambio aereo, a name that reflected its conventional nature ${ }^{29}$.

Furthermore, the price of "rechange" included a return on the credit period, an interest term ${ }^{30}$. The official price of exchange and "rechange" 'should provide to the creditor a non uncertain return. These prices are strongly disrupted by movements in the value of the different metallic moneys, ${ }^{31}$. In fact, the price of "rechange" included coverage for exchange rate variations: "rechange" was a guaranteed agreement as the overall price of financing in foreign currency was settled at the start. "Rechange" was essentially a spurious exchange rate transaction. It was a straight loan in foreign currency, covered for exchange rate risks. From this operation, the lender expected a return which was stipulated beforehand between the parties by fixing the "rechange" price ${ }^{32}$.

"Rechange" differs substantially from de Roover's dry exchange. According to de Roover's dry exchange transaction, the return was not stipulated beforehand and neither the lender nor the borrower could foresee how the exchange rate would swing, so that the return was always uncertain thus legitimating interest on shortterm credits ${ }^{33}$. Under Genoese law the lenders were allowed to guarantee the rate of "rechange" on a foreign bill of exchange sent back to repay the original lender.

The operation had several advantages. First, the lender received a return, since the sum that the borrower returned was always higher than the sum initially advanced. This was because the spot Scudo di Marco exchange rate was generally lower than its "rechange rate"; eventually the difference between the two rates, net of commission, represented the price that the borrower had to pay in order to obtain a loan on the market. Second, even if the transaction consisted, under all respects, of

\footnotetext{
${ }^{25}$ A credit balance, usually, gave rise to a demand for lending, so as to fruitfully employ the available capital and avoid payment in specie. See Mandich, Pacte, p.112.

${ }^{26}$ Mandich, “Fiere”, pp. 263-64; Peri, Negotiante, pt. 1, p. 76

${ }^{27}$ Peri, Negotiante, pt. 2, p. 63; Felloni, Moneta, p. 97 n.70; Mandich, ”Fiere”, p. 258.

${ }^{28}$ Mandich, Pacte, p. 45; Mueller, Venetian money.

${ }^{29}$ Boyer-Xambeau, Deleplace, Gillard “Crise”, p. 46; Rosselli, “Early views”, p. 66.

${ }^{30}$ This mechanism, indeed existed well before: the flow of credit from Florence to Venice depended on specie demand driven by the merchant galleys sailing to Levant in Spring (Mueller, Venetian money, p. 306); but one of the novelties introduced by the Genoese fairs is that now cycles of payment are marked by three-monthly fairs.

${ }^{31}$ Mandich, Pacte, p. 57.

32 In this rechange differs substantially from dry exchange. The return, in dry exchange, is not stipulated beforehand and neither the lender nor the borrower could foresee how the exchange rate would swing. See de Roover, "What is dry exchange?", p. 264.

${ }^{33}$ de Roover, "What is dry exchange?", p.264.
} 
a loan, the two operations - exchange and "rechange" - were formally independent, and therefore interest payment did not fall within usury law ${ }^{34}$.

"Rechange" lasted from one fair to another, but they were frequently rolled over, and evidence points to an average duration of one year; there is also evidence of continuous renewed rechanges that spanned nearly a decade ${ }^{35}$. They produced an annual yield that oscillated at around $10 \%$. In the more complex cases, various fairs, various currencies and various intermediaries were involved.

"Rechange" was a widespread practice. It had become an everyday way of investing funds, not only by merchant bankers but also by people who found themselves with cash in hand. Orders to agents and power of attorney included exchange as an investment opportunity to be exploited ${ }^{36}$. There is evidence that the same government (the Florentine Medici and the Venetian Senate in the $15^{\text {th }}$ century) became involved in borrowing on "rechange",37.

The strength of "rechange" over a foreign bill of exchange was the guarantee provided by the lender, by offering the lender a secured rate of interest, even in the crucial decades of the Genoese financial hegemony, between 1570 and 1620 . This explains how the Genoese were able to tap into the entire northern Italian merchant community for funds that could be subsequently loaned to the King of Spain, despite his frequent refinancing during this period and the vigor with which the magistrates of the two republics of Genoa and Venice defended the contract of the pactum de ricorsa against ecclesiastic prohibition ${ }^{38}$.

\section{Exchange and "rechange".}

"Rechange"is an agreement by which buyers and sellers agree to exchange currencies at the next exchange fair. Lenders are typically bankers or cambisti, acting on behalf of other people, and one reason why bankers or cambisti enter a "rechange" market is that they can be sure of the amount of foreign currency they will receive on exchange of their present loan. In fact bankers engaging in "rechange" avoid exchange rate risks by offsetting their assets and liabilities in Scudo di marco.

Bankers, on the third day of the fair, calculate exchange and "rechange" rates. The interest rate included in the "rechange" agreement, inclusive of transaction costs is:

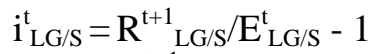

where $\mathrm{R}_{\mathrm{LG} / \mathrm{S}}^{\mathrm{t}}$ is the rechange rate calculated in $\mathrm{t}$, Lira Genoese for 1 Scudo di Marco, referring to the next fair, $\mathrm{E}_{\mathrm{LG} / \mathrm{S}}^{\mathrm{t}}$ is the spot exchange rate (cambio aereo), $\mathrm{i}_{\mathrm{LG} / \mathrm{S}}^{\mathrm{t}}$ is the domestic interest rate expressed in Scudi di Marco, where financing is realized by drafting bills in Lira.

Interest rates are calculated for the currencies for which we have a larger and more complete data set, Lira and Soldo Milanese. The starting point reflects data availability (1590, Presentation); the end point (1621, All Saints) is the last fair before transfer to Novi Ligure ${ }^{39}$. The average quarterly rate of interest was $2 \%$,

\footnotetext{
${ }^{34}$ de Roover, "What is dry exchange?”, p. 254. Particularly when rechange was paid in a fair different from the fair where the previous transaction was negotiated. A decree of Pius V of 1571 condemned dry exchanges, i.e. a bill of exchange from A to B and a subsequent bill, to take the proceeds back, from B to A, as the deal was considered artificially split into two, for the purpose of hiding interest payment. Transactions involving different fairs might imply, instead, a legitimate deal, such as a mercantile transaction or transfer of money from one place to the other, and so avoided breaking ecclesiastic laws. See Felloni, Moneta, p. 95; de Roover, "What is dry exchange?”, p. 252.

${ }^{35}$ Mandich, Pacte, ch.3.

${ }^{36}$ Ibid., pp.128-29; Mueller, Venetian money, pp. 336-37.

${ }^{37}$ Mueller, Venetian money, pp. 337-39.

${ }^{38}$ Mandich, Pacte, pp. 115-54

${ }^{39}$ The average number of bills of exchange dealt in Genoese fairs had a rapid decline thereafter (Felloni, “Asientos”).
} 
while there was no trend in debasement of either the Genoese or Milanese currencies and therefore, on average, the exchange rate was fixed at the relative metallic ratios. Covering for exchange rate fluctuations is a cost that was borne by the creditor: the cost is measured by the deviations between the "rechange" and the spot exchange rate at $\mathrm{t}+1$. It was a risky operation; fair exchange rates had relatively large plus or minus fluctuations, but the average gain or loss, over the long run was nil.

Table 1. Bisenzone. Interest and exchange variations in various currencies. Quarterly data.

\begin{tabular}{|c|c|c|c|c|}
\hline \multirow[t]{2}{*}{ Currency } & \multicolumn{2}{|c|}{ Exchange rate variations } & \multicolumn{2}{|l|}{ Interest } \\
\hline & average & st. dev. & average & st. dev. \\
\hline Genoa $^{\circ}$ & 0.00 & 1.18 & 1.91 & 0.91 \\
\hline Milan $^{\circ}$ & -0.11 & 1.48 & 2.05 & 0.81 \\
\hline Genoa* & 0.02 & 1.16 & 1.81 & 0.89 \\
\hline Venice* $^{*}$ & -0.12 & 1.56 & 1.74 & 0.94 \\
\hline Genoa§ & 0.05 & 1.10 & 1.91 & 0.79 \\
\hline 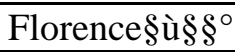 & $\mid-0.06$ & 1.15 & 1.35 & 0.79 \\
\hline
\end{tabular}

Source and method:

${ }^{\circ} 1590$ August-1621 August.

*1600 Easter -1621 August.

$\S 1601$ All saints-1606 Easter and 1608 All saints-1621 August.

Source: Da Silva, Banque.

The exchange deviations were not negligible and were the result of several factors; current account imbalances, current conditions of the money market, rumors about the silver shipped to Spain not arriving on time (i.e. on the forecasted conditions at maturity) and on the legal parity. Cambio aereo was a unit of account, but was not independent from the market rate of exchange. The exchange-rechange contract was usually provided with an escape clause to the debtor's advantage, allowing for the abandonment of the obligation and paying cash, if rechange at the agreed price were to prove too expensive due to a decline of the market price over time ${ }^{40}$. It was always possible to truncate the bill of exchange operation and to buy at the market price, manual exchange, the currency needed to pay the amount of the debt ${ }^{41}$. Cash had a cost, a premium or agio, over and above that of bank money: the commission to the cash broker who purchased specie and, on occasions, a tax ${ }^{42}$.

Eventually the cambio aereo or exchange rate at the fair could differ from the market rate of exchange but not systematically and only for a limited amount: should the market rechange and the next fair market exchange rate have diverged significantly, the entire finance mechanism would have been truncated by the debtor and would have eventually collapsed. Cambio aereo and the market rate of exchange could not drift far apart.

\footnotetext{
40 In a negotiation in which each party can renege on his contractual obligation, Cambio aereo needs to shadow the market rate. See also Greif, “Fundamental problem”, p. 254.

${ }^{41}$ Peri, Negotiante, pt. 3, pp.79-80.

${ }^{42}$ Mueller, Venetian money, pp. 346-47, reporting the course of a draft on Venice by Vincenzo Priuli in London (1505-1506) estimates such costs at no less than 5\%.
} 


\section{Bisenzone. A Genoese institution.}

Bankers and exchange dealers (mercanti di conto) acting at the fair were limited in number but they would act not only on their own account but also for the account of other debtors and creditors whom they represented and who were not present at the fair. Thus, the fair's clearing system acquired a very wide scope and had a large turnover. Bankers had the support of high ranking people and were requested to supply heavy caution money.

The fairs were actually a Genoese institution and the prominent role of the Genoese was firmly established. The Consul and the Magistrate were Genoese (although assisted by a Milanese and by representatives of other markets) as were the majority (2/3) of the advisors and of the Judge of the Court of Appeal ${ }^{43}$.

Payments in specie depended on the arrival of silver and gold that was directed to the asentista from the American mines. Delays arose from many causes and were rather frequent. In such cases, fairs were frequently delayed and in the most severe circumstances a moratorium was declared by the Magistrate postponing payments to the following fair. An interest was established for the delay and capitalized. The Genoese controlled the entire information process. Moratorium decisions that followed delays upon the arrival of the Spanish galleons were clearly in favour of Genoese debtors and burdened their creditors ${ }^{44}$. The same was true for the short term extension of the fairs ${ }^{45}$.

Delays only marginally affected the fairs because precious metal would eventually arrive and because coinage was only of use in paying/cashing net balances. Liquidation of net balances was of limited importance because the bigger the fair the more numerous were the transactions that were multilaterally balanced out and the less important was the ability to pay in cash. In their heyday, the Genoese fairs had the largest share of compensation over total payments compared with the other fairs ${ }^{46}$.

Fairs were a Genoese jurisdiction and this institutional arrangement supplemented the self-enforcing contractual relations between bankers in different fairs ${ }^{47}$.

\section{Equilibrium interest rates.}

The success of a cambista, a lender on foreign exchange, lay in his ability to foresee the movement of the various exchange rates, in his own city and other commercial and financial centres. He had to plan his credit supply in order to exploit the divergences among the different exchange rates, which corresponded to the vagaries in the demand for credit: a fall in the local rate or an increase in the foreign rate would have increased the lender's profit and viceversa. The Cambista, therefore, had to be aware of the seasonal tendencies of the European money markets and, at the same time, had to keep up with any news that could influence the rate of exchange in the short term.

The Cambista at a fair of exchange had the opportunity to negotiate in various currencies chosen on the basis of the market where the bills of exchange were drawn - the drawee market. The price of "rechange" was a function of the

\footnotetext{
${ }^{43}$ Da Silva, Banque, p. 76.

${ }^{44}$ According to Da Silva, ibid., pp. 167-69, the arrival delays of the ships from the Americas, explain all delays in maturity agreed on Bisenzone.

${ }^{45}$ Ibid., pp. 83-84. Fairs instead guarantee the fiscal exemption on such operations: agents do not communicate, so transactions are not taxed. See ibid., p. 70.

${ }^{46}$ Ibid., pp.135-40.Da Silva presents some examples where compensation accounts for roughly $1 / 5$ of total payments (the sum of exchange and rechange operations.

${ }^{47}$ Greif, "Fundamental problem", p. 264. The Genoese operated with all currencies, but all deals in Lira were carried out by Genoese bankers.
} 
larghezza (ease) or strettezza (tighteness) of the drawee market, and it reflected the conditions of the local money markets.

The demand for foreign exchange for this purpose would depend not only on the interest rates in the two currencies, but also on the expected exchange rate at investment maturity. Two factors had to be considered when evaluating the investment: 1) the rate of interest; 2) the effect of the appreciation of the foreign currency (a positive adjustment) or of the depreciation (a negative adjustment ${ }^{48}$. Money raising was not confined to the Ligurian city. Some evidence shows that in Venice, for example, a great deal of money was invested through Genoese and Tuscan bankers dealing with exchange fairs ${ }^{49}$. In a competitive financial market any cambista had to be impartial in dealing with both domestic and foreign investments and between foreign investments in different markets and currencies, working with a given level of expectations on exchange rate variations and at a given level of risk. Any investor would expect to earn the same rate of return, regardless of the currency in which the investment was denominated (Lira, Soldo or other currencies) ${ }^{50}$.

On average "Rechange" rolled over 4 or 5 fairs. The overall financing can be considered the result of the iteration of an elementary operation between two successive fairs, so the choice of the currency on which to secure a debt might be broken down into a sequence of simple operations from fair to fair.

Let us examine the exchange-rechange between $t$ and $t+1$.

Taking into account two currencies, i.e. the Lira and the Soldo (SM), interest rate parity requires ${ }^{51}$ :

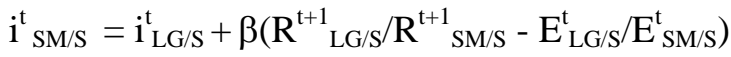

There could be a constant in the relationship as different bankers are involved, and a default risk is to be included as well (country risk):

$\mathrm{i}_{\mathrm{SM} / \mathrm{S}}^{\mathrm{t}}=\alpha+\mathrm{i}_{\mathrm{LG} / \mathrm{S}}^{\mathrm{t}}+\beta\left(\mathrm{R}_{\mathrm{LG} / \mathrm{S}}^{\mathrm{t}+1} \mathrm{R}_{\mathrm{SM} / \mathrm{S}}^{\mathrm{t}+1}-\mathrm{E}_{\mathrm{LG} / \mathrm{S}}^{\mathrm{t}} / \mathrm{E}_{\mathrm{SM} / \mathrm{S}}^{\mathrm{t}}\right)$

Under perfect capital mobility, $\beta=1$ and the real interest rates should be equal. If the exchange rates do not change, $\mathrm{R}_{\mathrm{LG} / \mathrm{S}}^{\mathrm{t}+1} \mathrm{R}_{\mathrm{SM} / \mathrm{S}}^{\mathrm{t}+1}=\mathrm{E}_{\mathrm{LG} / \mathrm{S}}^{\mathrm{t}} / \mathrm{E}_{\mathrm{SM} / \mathrm{S}}^{\mathrm{t}}$ and interest rates are balanced.

Under the above condition, a Lira invested in Bisenzone for three months, subsequently converted into a Scudo di Marco at the fair exchange rate and reconverted, together with interest, back into Lira at maturity with possible fluctuations in the exchange rate already accounted for, would equal the return from a Soldo invested in Bisenzone for three months, after converting the Soldo in Scudo di Marco at the fair exchange rate and the principal plus the interest rate back to Lira at maturity, taking into account the possible default risk connected to the debtor's trustworthiness.

\footnotetext{
48 Appreciation or depreciation is a measure of risk connected with investment in different currencies. It is measured by the exchange rate variance and can influence investment decisions according to the propensity toward risk of the different investors. Assume that a large variability will probably not be adeguately covered and will leave some risk for the exchange dealer.

${ }^{49}$ Venice played a crucial role, considering its active balance with Flanders which put her bankers in a very solid position. See Mandich, Pacte, p. 94.

${ }^{50}$ The relevance of the three markets can be estimated from data on protested bills of exchange: in the early the seventeenth century, Milan, Venice and Lyon were the most prominent markets for negotiating bills of exchange 'originating' in Bisenzone. See Da Silva, Banque, pp.118-19.

${ }^{51}$ The subscript has the sole purpose of showing how a banker negotiated: in this case the initial financing was in Lira; it was subsequently converted into Scudo di Marco to eventually return Lira to the Genoese.
} 
Transactions in different currencies might not diverge, in general, from profitability in Lira, given that correspondents of Genoese bankers were frequently very active in the most important markets and currencies: they knew the markets and transacted in different currencies for a modest commission. For example a Genoese financer, who was willing to raise sums in Milan in Soldo had to pay several commissions, but the overall amount was limited: a commission on "rechange" of $0.33 \%$ and another for the agents and correspondents that was usually kept somewhere between 0.25 and $0.50 \%{ }^{52}$. The cost of financing in a currency which was not the financer currency and which was independent from the market where funding was raised, could be estimated, according to an example reported by Da Silva, at between 1 and $2 \%^{53}$, subject to variations depending on the amount transacted. The commission was paid by the Genoese, who transacted in Soldo, and by the Milanese, who transacted in Lira. ${ }^{54}$

Transaction costs, cost of information and the like built a no-transaction band around parity and allowed for some margin of variation. If the interest differential stayed within the no-transaction band, capital could flow, with a certain degree of freedom, among the different markets and at the agreed prices there was no room left for competitive arbitrage between different currencies, taken two by two.

The commission was influenced by divergences in market rates of interest, specific market crises, the intervention of the local authorities and market disruptions, as already noted.

\section{A test of capital markets integration.}

Before moving on to a formal test of the integration of short term financing operations in the different fairs and given the fixed exchange rates prevailing at the time, the co-movements of relative interest rates will be examined (figure 1).

Figure 1. Interest rate yearly differences in Bisenzone and Milan

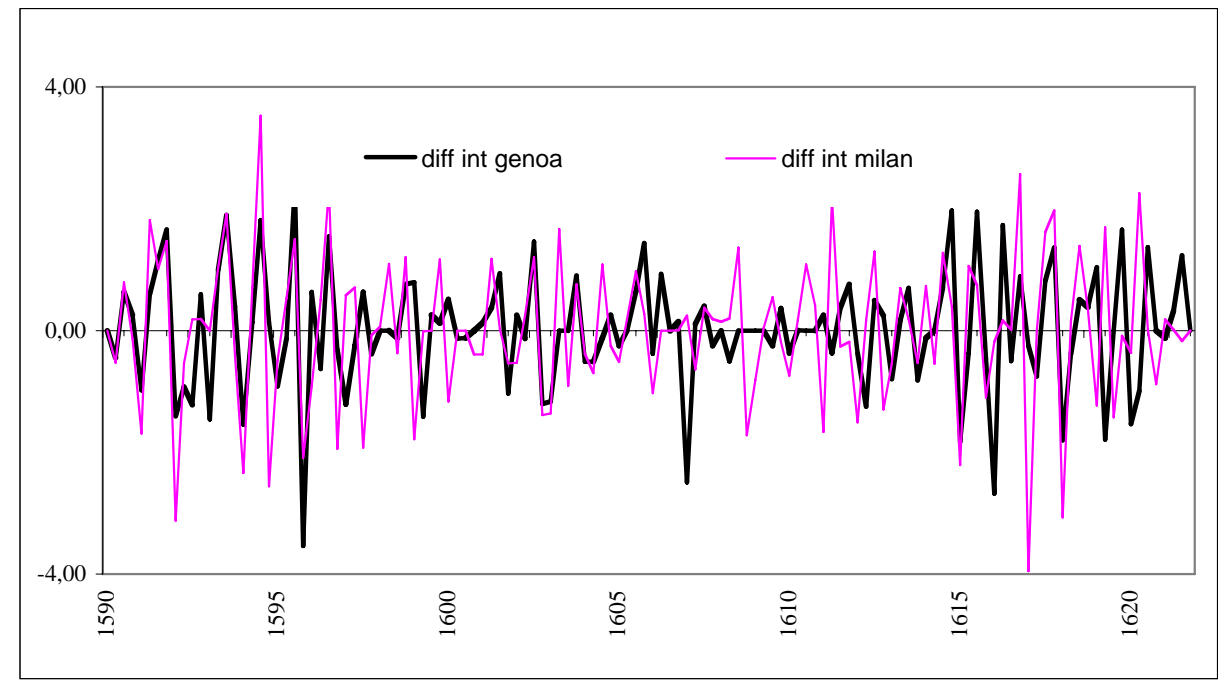

52 Boyer-Xambeau, Deleplace, Gillard, Banchieri, p. 48; Peri, Negotiante, pt. 1, pp. 89-98, 166-80; Ghilino, Banchiere, p.16. It reached 1.5\%-2\% when the endorsement (fidanza) was added. It seems that endorsement was frequent with rechange operations (Lapeyre, “Contribution”, p. 121).

The market commission varied according to the fairs. It is reported to be 0.66 in Lyon and reached 1.66 in Messina and Palermo (Boyer-Xambeau, Deleplace, Gillard, Banchieri, p. 48).

${ }^{53}$ Da Silva, Banque, p. 312.

54 ، ....ils ordonnaient de remettre 2.500 écus à Palerme ou à Messine, là ou’ le cors était le plus élevé, et de tirere un somme identique sur l'autre de ces places, si entre les deux il y avait une difference d'un denim carlino. Ces changes doulbles leur rapportaient ainsi un gain de $2 \%$, car les conditions demendées se réaliserènt: Messine cota 331/2 et Palerme, 34.’ Da Silva, Banque, p. 312, reported from Peri, Negotiante, pt. 1, pp.129-30. 
Interest rates in Soldo and Florentine Ducat are positively correlated with Lira interest but for a couple of periods. The correlation remains rather strong once one starts to examine the first differences; it fades away with the 1606 crisis and recovers slightly four or five years later. This crisis completely separated Bisenzone from Venice and Florence and the previous strong link with Milan was weakened. According to Da Silva the crisis lasted 6 years and marks a sharp break in the series. Interest rates peaked in Genoa in 1593-94, 1596, 1602-03 and in 1606-07 (tempi periculosi e difficili) ${ }^{55}$ together with the King of Spain's default of payment leading to the stringency of the money market in Genoa. The following were all associated with positive interest premiums ${ }^{56}$ : Philip II's bankruptcy in 1596 tightened the bankers credit primarily in Genoa; the crisis due to the delay in silver shipments in 1606; the enforced delay in payments and the agreed low interest rate in Genoa (negative interest differentials at the1606 Easter and August fairs) together with the subsequent announcement of a new suspension by the King of Spain and the tightening of the Genoese money market in 1608. After all that, credit conditions were relieved and interest in Genoa reached a comparatively low level when gold and silver finally arrived in abundant supply ${ }^{57}$.

The correlation between Lira and Venice Grosso is rather weak and its absence marks the structural separation between these two markets.

Table 2. Correlation coefficients of various interest on rechange operations with Lira interest.

\begin{tabular}{|l|l|l|l|l|l|}
\hline & \multicolumn{2}{|l|}{ Lira-Soldo } & Lira-Grosso & \multicolumn{2}{l|}{ Lira-Ducat } \\
\cline { 2 - 6 } & $1590.3-1606.3$ & $1608.4-1621.3$ & $1600.2-1621.3$ & $1601.4-1606.2$ & $1608.4-1621.3$ \\
\hline interest & 0.73 & 0.28 & 0.25 & 0.63 & 0.16 \\
\hline$\Delta$ interest & 0.59 & 0.24 & 0.19 & 0.42 & -0.06 \\
\hline
\end{tabular}

Da Silva, Banque.

The integration of the foreign bills of exchange market between Genoa and Milan is tested first in terms of deviations between couples of equilibrium interest rates. The exchange rate is fixed except for temporary deviations, as suggested by exchange rate time series data (table 1), and since expected variations in the exchange rate are on average zero, the term in brackets in equation (3) can be ignored. The zero arbitrage condition (1) is written as

$\mathrm{i}_{\mathrm{LG} / \mathrm{S}}^{\mathrm{t}}=\alpha+\mathrm{i}_{\mathrm{SM} / \mathrm{s}}^{\mathrm{t}}+\mathrm{d}_{\mathrm{t}}$

\footnotetext{
${ }^{55}$ Spinola’s correspondence reported in Da Silva , Banque, p. 591,n.174.

${ }^{56}$ Da Silva, Banque, p.312.

${ }^{57}$ The large arrival of silver and gold in Genoa are documented by the representatives of Florence, Venice and Mantua and reported in table 46 by Da Silva, Banque, p. 171.
} 
Figure 2. Deviations between the three months interest rate on rechange in Scudo di Marco Via Lira Genoese and Soldo Milanese.

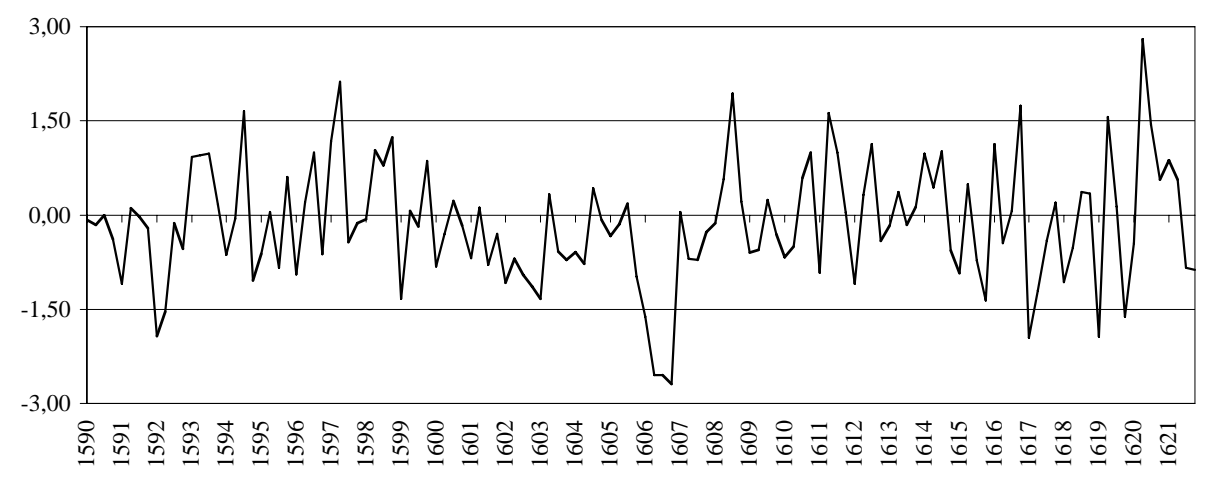

$d_{t}$ represents the deviations from the arbitrage condition in period t. If deviations between the two interest rates are permanent in nature (i.e., non-stationary) the theory can be straight reject. Table 1 has already provided evidence that the difference in interest rates is stationary with expected value of zero. Deviations $d_{t}$ are charted in figure 2. They oscillate at around zero, with constant variance. A band constructed around zero $\pm 1.5 \%$ includes the majority of relative observations in the period $1590-1621$ (10\% of the total quarterly observations remain outside the band). During the crisis of 1606 Lira interest rate was higher than Soldo interest, as Genoa was more directly influenced by the delay in the shipment of silver from the Americas and the consequent "penuria grande del contante" ${ }^{58}$.

Co-integration offers an alternative and more informative method for checking the theory. If the zero arbitrage condition holds, the sequence formed by $\mathrm{i}_{\mathrm{LG} / \mathrm{s}}^{\mathrm{t}}$ should be co-integrated with the sequence of the rates of interest in different currencies, expressed in Scudi di Marco $\left(\mathrm{i}_{\mathrm{J} / \mathrm{S}}^{\mathrm{t}}, \mathrm{J}=\mathrm{SM}, \mathrm{GV}, \mathrm{DF}\right)$. The arbitrage condition assertains that a linear combination exists in the form of $\mathrm{i}_{\mathrm{LG} / \mathrm{S}}^{\mathrm{t}}=\mathrm{a}_{0}+\mathrm{a}_{1} \mathrm{i}_{\mathrm{J} / \mathrm{S}}^{\mathrm{t}}+\mathrm{u}_{\mathrm{t}}$ such that the error process $\mathrm{u}_{\mathrm{t}}$ is stationary, or $\mathrm{I}(0)$, and the co-integrating vector is such that $\mathrm{a}_{0}$ differs insignificantly from zero and $\mathrm{a}_{1}$ from unity (no interest rate premium).

The estimation strategy advanced by Pesaran, Shin, and Smith has been applied ${ }^{59}$. At the first stage the existence of the long run relation between the two interest rates is tested by computing the F-stat. to test the significance of the lagged levels of the variables in the error correction form of the underlying Autoregressive Distributed Lag (ARDL) model $\left(\delta_{1}=\delta_{2}=0\right)$. At the second stage the coefficients of the long run relation are estimated.

The maximum order of the lags has been chosen according to the Schwarz Bayesian Criterion and the result is $(0,1)$. The error correction version of the $\operatorname{ARDL}(0,1)$ model in the variables $\mathrm{i}_{\mathrm{LG} / \mathrm{S}}^{\mathrm{t}}$ and $\mathrm{i}_{\mathrm{J} / \mathrm{S}}^{\mathrm{t}}$ is given by:

$\Delta \mathrm{i}_{\mathrm{LG} / \mathrm{S}}^{\mathrm{t}}=\alpha_{0}+\delta_{1} \mathrm{i}_{\mathrm{J} / \mathrm{S}}^{\mathrm{t}-1}+\delta_{2} \mathrm{i}_{\mathrm{LG} / \mathrm{S}}^{\mathrm{t}-1}+\alpha_{1} \Delta_{\mathrm{i}_{\mathrm{J} / \mathrm{S}}^{\mathrm{t}-1}}+\alpha_{2} \Delta_{\mathrm{LG} / \mathrm{S}}^{\mathrm{t}-1}+\varepsilon^{\mathrm{t}}$

The long run relation (t values in brackets) is

Genoese Lira - Milanese Soldo.1590.3-1606.1

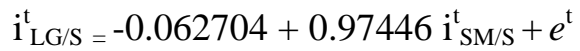

$$
(-0.13718) \quad(5.1250)
$$

${ }^{58}$ Letters sent to Mantua in 3.6.1606, reported by Da Silva, Banque, p. 168 n.1.
${ }^{59}$ Pesaran, Shin, Smith, “Testing”. 
Genoese Lira - Milanese Soldo.1590.3-1621.3

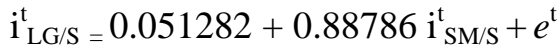

$$
\text { (0.14153) (5.3906) }
$$

Genoese Lira- Venetian Grosso.1600.2-1621.3

$\mathrm{i}_{\mathrm{LG} / \mathrm{S}}^{\mathrm{t}}=1.1106+0.38811 \mathrm{i}_{\mathrm{GV} / \mathrm{S}}^{\mathrm{t}}+e^{\mathrm{t}}$

$$
\text { (3.0840) (2.1281) }
$$

Genoese Lira - Florentine Ducat.1600.2-1621.3

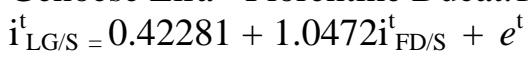

$$
\text { (1.2351) (4.2272) }
$$

The error correction representation for the Selected ARDL model is:

Genoese Lira - Milanese Soldo.1590.3-1606.1

$$
\begin{gathered}
\Delta \mathrm{i}_{\mathrm{LG} / \mathrm{S}}^{\mathrm{t}}=-0.59816 e^{\mathrm{t}-1}+0.58288 \Delta \mathrm{i}_{\mathrm{LG} / \mathrm{S}}^{\mathrm{t}-1}+u^{\mathrm{t}} \\
\quad(-7.0602) \quad(7.4924) \\
e^{\mathrm{t}-1}=\mathrm{i}_{\mathrm{LG} / \mathrm{S}}^{\mathrm{t}}-0.062704+0.97446 \mathrm{i}_{\mathrm{SM} / \mathrm{S}}^{\mathrm{t}}
\end{gathered}
$$

Genoese Lira - Milanese Soldo.1590.3-1621.3

$$
\begin{aligned}
\Delta \mathrm{i}_{\mathrm{LG} / \mathrm{S}}^{\mathrm{t}}=-0.53752 e^{\mathrm{t}-1}+0.47724 \Delta \mathrm{i}_{\mathrm{LG} / \mathrm{S}}^{\mathrm{t}}+u^{\mathrm{t}} \\
(-8.0109)
\end{aligned}
$$

$e^{\mathrm{t}-1}=\mathrm{i}_{\mathrm{LG} / \mathrm{S}}^{\mathrm{t}}-0.051282+0.88786 \mathrm{i}_{\mathrm{SM} / \mathrm{S}}^{\mathrm{t}}$

Genoese Lira - Venetian Grosso. 1600.2-1621.3

$\Delta \mathrm{i}_{\mathrm{LG} / \mathrm{S}}^{\mathrm{t}}=-0.50197 e^{\mathrm{t}-1}+0.19482 \Delta \mathrm{i}^{\mathrm{t}-1}{ }_{\mathrm{LG} / \mathrm{S}}+u^{\mathrm{t}}$

$(-5.4627)$

$e^{\mathrm{t}-1}=\mathrm{i}_{\mathrm{LG} / \mathrm{S}}^{\mathrm{t}}-1.1106+0.38811 \mathrm{i}_{\mathrm{GV} / \mathrm{S}}^{\mathrm{t}}$

Genoese Lira- Florentine Ducat. 1600.2-1621.3

$\Delta \mathrm{i}_{\mathrm{LG} / \mathrm{S}}^{\mathrm{t}}=-0.61344 e^{\mathrm{t}-1}+0.32147 \Delta \mathrm{i}^{\mathrm{t}-1}{ }_{\mathrm{LG} / \mathrm{S}}+\mathrm{u}^{\mathrm{t}}$

$$
\text { (-6.6502) (3.1450) }
$$

The coefficient of the error correction term, $e^{\mathrm{t}-1}$ (close to -0.5 ), is statistically meaningful, has the correct sign and suggests a strong relation between the level variables in (5), i.e., the interest rates at the fairs of Milan, Florence, Venice and Bisenzone and a rapid movement towards equilibrium adjustment (in two quarters $)^{60}$.

Figure 3 charts the relation between the interest rate of Lira, Soldo and Grosso. The $45^{\circ}$ line $-\mathrm{a}_{0}=0, \mathrm{a}_{1}=1$, i.e. nil country risk and perfectly synchronized capital movements - represents the situation of perfect capital market integration.

${ }^{60}$ Residuals have been tested for stationarity:
\begin{tabular}{|l|l|l|}
\hline \multicolumn{2}{|l|}{} & test statistics \\
\hline Genoese Lira- Milanese Soldo & $1591.1-1606.1$ & $1591.1-1621.3$ \\
\hline Dickey-Fuller & -8.9005 & -12.0149 \\
\hline Aug.Dickey-Fuller (lag: 1 ) & -4.5756 & -8.5176 \\
\hline Genoese Lira -Venetian Grosso & $1601.2-1621.3$ & \\
\hline Dickey-Fuller & -10.8413 & \\
\hline Aug.Dickey-Fuller (lag: 3) & -3.7260 & \\
\hline Genoese Lira - Florentine Ducat & $1600.4-1621.3$ \\
\hline Dickey-Fuller & -8.8998 & \\
\hline Aug.Dickey-Fuller (lag: 1 ) & -4.8500 & \\
\hline
\end{tabular}


Figure 3. Soldo, Grosso and Lira interest rates at Bisenzone and long run relations.

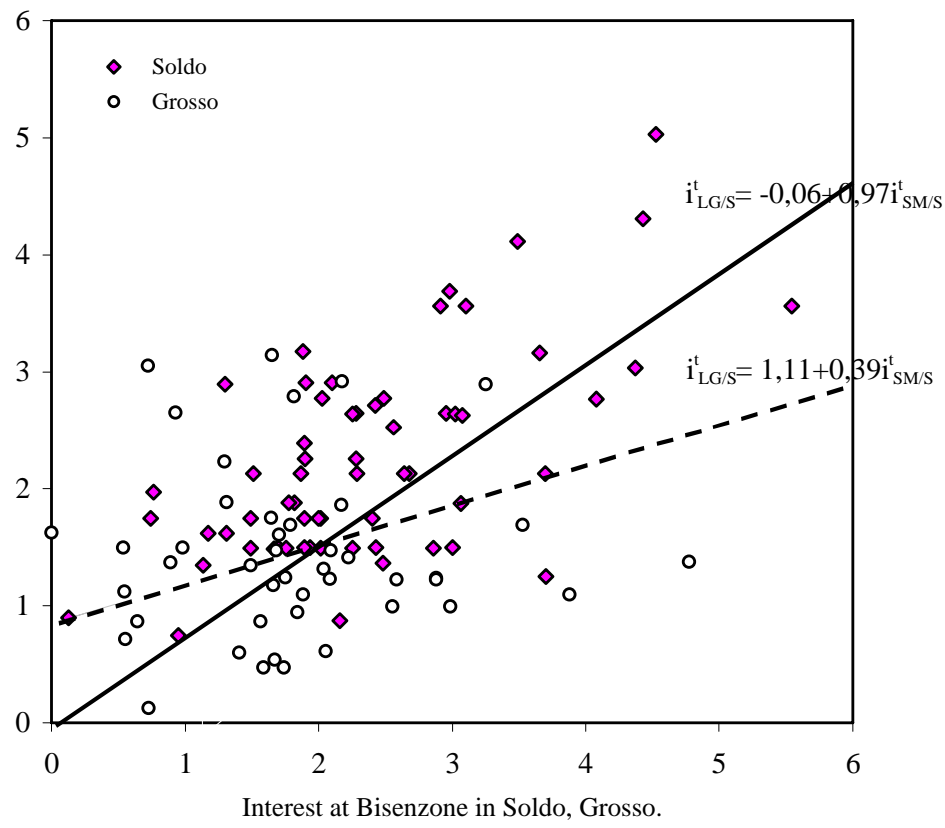

Long run estimates referring to Genoa and Venice and Genoa and Florence report $\mathrm{a}_{0}>0$, a positive country risk in respect to Lira ${ }^{61}$. This was a direct consequence of the risk connected with Genoa's bankers heavy involvement in the asientos $^{62}$. The Genoese money market was directly affected by the bad news related to the King of Spain's trustworthiness and to the arrival of his galleons, so that interest rates on short term financing through foreign bills of exchange in Genoa were at premium over Venetian and Florentine rates. Florence on the other hand was, at least in part, affected by the same rumours that affected the Genoese market. This was because Leghorn, Tuscany's main port, was also involved in the shipment of the Spanish silver, and so the interest rate in Florence was influenced by the same cycle to that in Genoa. The econometric result for Genoa and Florence - $\mathrm{a}_{1}$ close to 1 - points to close co-movement of the two interest rates.

Milan capital market was directly linked to Genoa and shared Genoa characters, both in terms of risk and fluctuations, $\mathrm{a}_{0}$ close to 0 and $\mathrm{a}_{1}$ close to 1 . Genoese bankers had additional security collateral in the control they exercised over important Milanese sources of revenue: the Balbi, for example, were entitled to collect excise duties in the duchy of Milan [dazio sulla mercanzia] and had the monopoly of the wine and salt trade together with other privileges.

The Genoa and Venice capital markets were not strictly linked. Venetian bankers' involvement with Genoese bankers refinancing was frequent and was an indisputable source of revenue, with Venice acting as a secondary rechange market - but Venice was only indirectly influenced by the vagaries and the anxieties of the Genoese money market. The Venice money market was more greatly influenced by the respective trade conditions and it had an independent life of its own, $\mathrm{a}_{1}=0,39$.

\footnotetext{
${ }^{61}$ The relationship between Lira and Grosso and between Lira and Ducat, are subject to limited data availability. The relatively short period of observation together with the 1606 crisis suggest a very cautious interpretation.

${ }^{62}$ The few available data for Naples seem to confirm our conclusions. Naples interest rates lie on a straight line with a positive constant and a slope close to 1 . Genoese capitalists had a critical role in $16^{\text {th }}$ century Naples, which was used by the Spanish Crown as a main financing center for the war in the Low Countries. By 1563, Genoese investors owned almost a quarter of the entire Neapolitan public debt (Calabria, Empire, p. 115). Because of war, Naples represented a high risk country, which accounts for the positive constant.
} 
The high Lira rate of interest on rechange was not a reflection of a Genoese tight capital market. Supply of capital in Genoa, at that time, was generally abundant and long term interest rates on the Genoese public debt were lower than those in Venice, Milan Florence and Naples, while the short-term Lira interest rates at Bisenzone was generally higher than interest on other currencies.

This was a curious inversion that can be only explained as being due to the more risky operations conducted by Genoese bankers, in connection with the asientos (table 3)

Table. 3. Yearly interest rates on rechange in Bisenzone and on long -term loans in some Italian markets.

\begin{tabular}{|l|r|r|r|r|r|r|r|r|r|r|}
\hline & \multicolumn{4}{|c|}{ Bisenzone } & \multicolumn{5}{c|}{ Government loans } \\
\cline { 2 - 12 } & $\begin{array}{c}\text { Genoa } \\
\text { (Genoa) }\end{array}$ & $\begin{array}{l}\text { Milan } \\
\text { (Milan) }\end{array}$ & $\begin{array}{l}\text { Venice } \\
\text { Venice }\end{array}$ & $\begin{array}{l}\text { Forence } \\
\text { Florence Naples }\end{array}$ & Genoa & Milan & Venice & Florenc & Naples \\
\hline $1571-75$ & & & & & & 3.0 & & 8 & & 9.1 \\
\hline $1576-80$ & & & & & & 3.0 & 8 & & & 8.2 \\
\hline $1581-85$ & & & & & & 3.3 & & & & 8.5 \\
\hline $1586-90$ & & & & & & 3.3 & & 5 & & \\
\hline $1591-95$ & 9.11 & 9.79 & & & $6.92 *$ & 3.4 & 7.5 & & 5 & \\
\hline $1596-1600$ & 7.78 & 9.84 & & & & 3.6 & 7 & & 5 & 7.4 \\
\hline $1601-05$ & 9.13 & 8.69 & 7.75 & 5.86 & & 4.0 & 7 & 3.5 & 5 & \\
\hline $1606-10$ & 8.6 & 7.18 & 6.47 & & & 3.5 & & 4 & 5 & 7 \\
\hline $1611-15$ & 6.04 & 7.03 & 6.24 & 3.25 & & 3.5 & & & 5 & \\
\hline $1616-20$ & 5.72 & 7.62 & 6.54 & 5.19 & & 3.5 & & 5 & 5 & \\
\hline $1621-25$ & 8.66 & 9.16 & 8.00 & 5.78 & & 3.5 & & 5 & 5 & \\
\hline $1626-30$ & 6.6 & 11.97 & & & & 3.2 & & 5 & 5 & \\
\hline
\end{tabular}

* Years 1591-93

Sources: Marsilio, 'Che interesse'; Giacchero, Seicento, pp. 676-78; Cuneo, Memorie, pp. 308-10; Pezzolo, Finanza;

Pezzolo, "Istituzioni”, pp. 471-78; Calabria, Cost of empire, pp. 143 ff.; Mantelli, Alienazione, pp. 87 ff.; Da Silva, Banque

\section{Conclusions.}

The diffusion of the Genoese fairs of exchange in Italy between 1550 and 1620 is both the result of the continuous demand for private loans from the Spanish Crown needed to support the expansionist war policies of Charles V and Philip II, and the fact that Genoa was at the center of the route from Seville, where American silver reached Europe, and the Levant, where silver was mostly needed. The Genoese acted on behalf of the Spanish crown to provide two fundamental services. The first involved the transfer of American silver to Spain and its conversion into gold which was used to pay military expenses in the Low Countries. The second involved the provision of short-term (frequently extended) credit to the Spanish crown. The Bisenzone fairs were central to both processes. The Genoese arranged international bills of exchange at the fairs and more importantly, they used northern Italian capital to finance their operations.

The mobilization of capital involved the pactum de ricorsa and represented a financial innovation. Basically, the ricorsa involved Genoese bankers entering into contract with others and which meant that Genoese bankers entered a contract where they borrowed money in the currency denominated by the lender. As a consequence the Genoese bore the exchange risk. The transactions took the form of 
balanced foreign bills of exchange, presumably because this was an established financial instrument and because it evaded Papal bans on usury.

Lending to the King of Spain, through the asientos, was a risky operation but the reward was comparatively high. The Genoese were able to successfully manage their long-term lending to the King of Spain for several decades partly because Genoa occupied a crucial position along the silver transfer route to the Levant and partly because Genoese overall credit balance put them on a safe pedestal. Genoese were safely in charge of the management of the most important international medium term capital market of the time. "Rechange" renewed continuously. It spread the risk deriving from the funding of the Spanish debt over a wide market which involved many investors and granted high profits, in comparison with the limited alternatives available. The Bisenzone fair effectively integrated the key northern Italian financial markets: Genoa was directly linked to Milan because the Genoese had direct control of the Duchy of Milan, while Florence and Venice capital markets were more independent and less risky, not being directly involved with the asientos.

The Bisenzone fair was a credit market with its own currency and a wide and trusted network . It was efficiently managed under Genoese law and under Genoese legal and political leadership. It was efficiently integrated in the global network which acted as a reservoir, pumping money out when needed. Although, with a hint of contempt, the Tuscans called Bisenzone fiera senza luogo, [fair without a place] it was in many ways an important a capital market which operated on an international scale and was firmly backed by the seal of the Genoese state. The success of the financial operations that took place in Bisenzone provided the expertise on which the later merchant powers of North Western Europe were able to develop during the seventeenth century, after surviving the horrors of the Thirty Years War.

\section{References}

Bitossi, Carlo. Il governo dei magnifici. Patriziato e politica a Genova fra Cinque e Seicento. Genova: ECIG, 1990.

Boyajian, James C. Portuguese bankers at the court of Spain, 1626-1650. New Brunswick, NJ: Rutgers University Press, 1983.

Boyer-Xambeau Marie-Thérèse, Ghislain Deleplace, and Lucien Gillard. Banchieri e principi. Moneta e credito nell'Europa del Cinquecento. Torino: Einaudi, 1991. [originally published in French in 1986.]

. "La crise du système de change Lyonnais a la fin du XVI siècle." Revue Internationale d'Histoire de la Banque, no.32-33 (1986) : 145-65.

Braudel, Fernand. Civiltà e imperi del Mediterraneo nell'età di Filippo II. Torino: Einaudi, 1976. [originally published in French in 1966].

Broens, Nicolàs. Monarquia y capital mercantil: Felipe IV y las redes comerciales portuguesas (1627-1635). Madrid: Ediciones de la Universidad Autònoma de Madrid, 1989.

Brulez, Wilfrid., "L'éxportation des Pays-Bas vers l'Italie par voie de terre au milieu du XVI siècle.” Annales E.S.C. 14, no. 3 (1959) : 461-91.

. "De handelsbalans der Nederlanden in het midden van de $16^{\mathrm{e}}$ eeuw."

Bijdragen voor de geschiedenis der Nederlanden 21, (1966-67): 278-310.

. "Anvers.” Vierteljahrschrift für sozial- und wirtschaftsgeschichte 54, no. 1

(1967): 75-99.

Calabria, Antonio, The cost of empire, Cambridge: Cambridge University Press, 1991. 
Castillo Pintado, Alvaro. "Dans la monarchie espagnole du XVIIe siècle. Les banquiers portugais et le circuit d'Amsterdam.” Annales E.S.C. 19, no. 2 (1964): 311-16.

Chaudhuri, Kirti N. "The economic and monetary problems of European trade with Asia during the seventeenth and eighteenth centuries." Journal of European Economic History 4. no. 2 (1975): 323-58.

Conklin, James. "The theory of Sovereign debt and Spain under Philip II.” Journal of Political Economy 106. no. 3 (1998): 483-513.

Contarini, Nicolò. Historie venetiane, MS in Venice, State Archives, Misc. Codici, I, Storia veneta, 79.

Cuneo, Carlo. Memorie sopra l'antico debito pubblico, Genova: Stamperia dei Sordi Muti: 1942.

Da Silva, Josè-Gentil., Marchandises et finances. 2. Lettres de Lisbone, 15631578. Paris : SEVPEN, 1956.

. Banque et crédit en Italie au XVII siècle. Paris : Klincksieck, 1969.

De Roover, Raymond., "What is dry exchange? A contribution to the study of English mercantilism.” Journal of Political Economy 52. no. 2 (1944): 250-66.

Doria, Giorgio. "Conoscenza del mercato e sistema informativo: il know-how dei mercanti-finanzieri genovese nei secoli XVI e XVII." In La repubblica internazionale del denaro tra XV e XVII secolo, edited by Aldo De Maddalena, and Hermann Kellenbenz, 57-121. Bologna: Il Mulino, 1986.

. Moneta, credito e banche in Europa: un millennio di storia, Genova:

Banca Carige, 1997.

"Asientos, juros y ferias de cambio desde el observatorio genoves (1541-

1675)”. In Felloni, Giuseppe. Scritti di storia economica, Genova: Società Ligure di Storia Patria, 1998.

Gelabert, Juan. "Castile, 1504-1808." In The rise of the fiscal state in Europe c. 1200-1815, edited by Richard Bonney, 201-41. Oxford: Oxford University Press, 1999.

Giacchero, Giulio. Il Seicento e le compere di San Giorgio, Genova: SAGEP, 1979

Ghilino, Silvano. Un banchiere del '600: Stefano Balbi. Affari di stato e fiere dei cambi, Genova: Università di Genova, 1996;

Girard, André. "Les étrangers dans la vie économique de l'Espagne aux XVI et XVII siècles.” Annales H. E. S. 5, no. 4 (1933): 567-78

Goris, Jean Albert . Etudes sur les colonies marchandes méridionales (portugais, espagnoles, italiens) à Anvers de 1488 à. Louvain: Librairie Universitaire Vystpruyst, 1925.

Greif, Avner. "The fundamental problem of exchange: A research agenda in historical institutional analysis", European Review of Economic History 4, no. 3 (2000): 251-84.

Kindleberger, Charles P. C. Spenders and hoarders. The world distribution of Spanish American silver. Singapore: Institute of Southeast Asian Studies, 1989.

Lapeyre, Henry. "Contribution à l'histoire de la lettre de change en Espagne du XIVe au XVIIIe siècle.” Anuario de historia economica y social 12, no. 1 (1968): $107-25$.

Lettres marchandes d'Anvers. Edited by Valentin Vàzquez de Prada. Paris: SEVPEN, 1960.

Mandich, Giulio. "Delle fiere genovesi di cambi, particolarmente studiate come mercati periodici del credito.” Rivista di storia economica 4, no. 3 (1939): 257-76.

. Le pacte de ricorsa et le marché italien des changes au XVIIe siècle, Paris : SEVPEN, 1953.

Mantelli, Roberto. L'alienazione della rendita pubblica e i suoi acquirenti dal 1556 al 1583 nel Regno di Napoli, Bari: Cacucci, 1997. 
Marcos Martìn, Alberto. "España y Flandes (1618-1648): la financiaciòn de la guerra”. In Calderòn de la Barca y la España del Barroco, edited by José AlcalàZamora and Ernest Belenguer. 15-39. Madrid: Centro de Estudios Polìticos y Constitucionales, Sociedad Estatal España Nuevo Milenio, 2001.

Marsilio, Claudio.'”Che interesse tiri interesse'. Un esempio di 'continuatione de' cambi' sulle fiere genovesi: 1600-1677.” Balbi Sei. Ricerche storiche genovesi, n. 0, 2004.

Mueller, Reinhold. The Venetian money market. Banks, panics, and the public debt, 1200-1500, Baltimore and London: Johns Hopkins University, 1997.

Neal, Larry. "How it all began: the monetary and financial architecture of Europe during the first global capital markets, 1648-1815." Financial history review 7, no. 2 (2000): 117-40.

Parker, Geoffrey. The army of Flanders and the Spanish road, 1567-1659. Cambridge: Cambridge University Press, 1972.

Peri, Giovanni Domenico. Il negoziante. Genova: 1697 (first ed. 1637).

Pesaran M.Hashem, Yongceol Shin, and Richard J.,Smith. "Testing for the Existence of a Long-Run-Relationship.” DAE Working Paper No. 9622, Cambridge, 1996.

Pezzolo, Luciano. Una finanza d'ancien régime. Il caso della Repubblica di Venezia, (forthcoming).

. "Istituzioni e sistemi finanziari in Italia tra Cinque e Seicento: un confronto tra la Repubblica di Venezia e lo Stato di Milano.” Acta Histriae 7. (1999): 471-78. . L'economia d'antico regime. Roma: Carocci, 2005.

Quatrefages, René. Los tercios españoles (1567-77). Madrid : Fundación Universitaria Española, 1979.

Rosselli, Annalisa, "Early views on monetary policy: the Neapolitan debate on the theory of exchange." History of Political Economy 32. no. 1 (2000): 61-82;

Thompson, I.I.A. "Castile: polity, fiscality, and fiscal crisis." In Fiscal crises, liberty, and representative government 1450-1789, edited by Philip T. Hoffman, and Kathryn Norberg, 140-80. Stanford: Stanford University Press, 1994.

Van der Wee, Hermann. The growth of the Antwerp market and the European economy. The Hague: Nijhoff, 1963.

Vàzquez de Prada, Valentin. "Gli uomini d'affari e i loro rapporti con la corona spagnola nella Fiandre (1567-1597).” In La repubblica internazionale del denaro tra XV e XVII secolo, edited by Aldo De Maddalena, and Hermann Kellenbenz, 243-73. Bologna: Il Mulino, 1986. 